\title{
The Reform of the UK's Auditor Independence Framework after the Enron Collapse: An Example of Evidence-based Policy Making
}

\author{
Stella Fearnley ${ }^{1}$ and Vivien Beattie ${ }^{2}$ \\ ${ }^{1}$ University of Portsmouth Business School \\ ${ }^{2}$ University of Glasgow
}

Following the collapse of Enron, the UK government set up a high level group of regulators and ministers to co-ordinate a review of the UK regulatory framework, including the key area of auditor independence. The Accountancy Foundation Review Board (Review Board), which was at the time responsible for the independent oversight of the UK accountancy professional bodies, took the leading role in the auditor independence review.

A programme of research was set up by the Review Board and studies were provided by other bodies. The results of the research were compiled into a paper which underpinned the Review Board's recommendations for change. This was fed into the government review process. In this paper, the research is summarised and the Review Board's evidence-based recommendations are presented and compared with the government's final position. Few differences are found. Insights are provided into the nature of the regulatory reform process and the quality of the evidence which underpinned it.

Key words: Auditor independence, UK government, post-Enron reform, accountancy profession oversight.

\section{SUMMARY}

Following the collapse of Enron, the UK government set up the Co-ordinating Group on Audit and Accounting Issues (CGAA), a high level group of regulators and ministers. The CGAA was

Correspondence to: Department of Accounting, Law and Management Science, University of Portsmouth Business School, Richmond Building, Portland Street, Portsmouth PO1 3DE. E-mail: stella.fearnley@port.ac.uk responsible for leading the review of the regulatory framework, including the key area of auditor independence, and for making recommendations for change. Both the chairman and the director of the Accountancy Foundation Review Board (Review Board), which was at the time responsible for the independent oversight of the UK accountancy professional bodies, were members of the CGAA.

In order to ensure that the policy discussions on the subject of auditor independence were properly 
informed, the Review Board commissioned a programme of research from leading academics and market research bodies. Other interested parties also prepared or commissioned further studies which were made available to the Board. Based on the findings of the research, the Enron concerns and a review of the UK regulatory framework for auditor independence, a series of recommendations for the enhancement of auditor independence were developed by the Review Board. These recommendations and the evidence which underpinned them were fed into the CGAA's decision-making process.

This paper has two objectives. The first objective is to provide, for academic readership, a summary of the research considered by the Review Board, together with the Review Board's recommendations for change to the UK auditor independence regime and the evidence which underpinned them. The second objective is to compare the auditor independence recommendations in the CGAA's final report with the Review Board's recommendations in order to evaluate the extent to which the Review Board's evidence-based research supported public policy development in this area.

Few differences are found between the Review Board's recommendations and the CGAA's final recommendations. The three principal forms of the CGAA's recommendations are found to be increased transparency and disclosure by audit firms about quality control; increased transparency and disclosure by companies about the activities of the audit committee; and enhanced disclosure of the breakdown of non-audit services. These are regulatory mechanisms which are generally low cost. A further key change is the rationalisation of the regime for auditor independence under the Auditing Practices Board. The most significant difference between the Review Board's recommendations and the final reforms is the establishment of a new audit monitoring unit, outside the control of the UK accountancy bodies, to inspect listed and public interest audits. This will be under the control of the successor body to the Review Board (The Professional Oversight Board for Accountancy (POBA)). The POBA will become part of the Financial Reporting Council (FRC), following the transfer of the Accountancy Foundation's key activities to the FRC.

Valuable insights are also provided into the nature of the sources of input to the UK's post-Enron reform programme for auditor independence. The policy making procedure is seen to be essentially evidence-based, with considerable reliance being placed on the results of academic research.

\section{INTRODUCTION}

The collapse of Enron, in November 2001, followed by the demise of Andersen (SEC, 2002) and the Worldcom scandal provided evidence of systemic failure in the US regulatory framework for financial reporting, and raised widespread beliefs that Andersen had compromised its independence as auditors.

The ensuing crisis of confidence in financial reporting and auditing spread to other countries, including the UK. Although there had been no comparable failures in the UK, where the regulatory framework has been claimed to be more robust (Hinks, 2002), public reassurance was needed. The UK government rapidly instigated reviews of key aspects of the UK regulatory framework. The process was led by the $\mathrm{Co}^{-}$ ordinating Group on Audit and Accounting Issues (CGAA) which was set up in February 2002 by the Secretary of State for Trade and Industry and the Chancellor of the Exchequer and was jointly chaired by two ministers. ${ }^{1}$ The review was wide-ranging and focused on financial reporting, auditing, corporate governance and the structure of the regulatory framework for audit and the accountancy profession. ${ }^{2}$

A key concern for the CGAA was the adequacy of the UK framework for auditor independence. A combination of circumstances which could undermine independence led to harsh criticism of Andersen. These were: (i) the firm was earning more from non-audit services provision than from the audit ( $\$ 25 \mathrm{~m}$ from audit and $\$ 27 \mathrm{~m}$ from nonaudit services) and non-audit services included assisting the company to devise accounting schemes compliant with US GAAP, which had the objective of keeping liabilities off the balance sheet,; (ii) Enron had been the partner's only client for some years and was the principal client of the firm's Houston office, thus the office and the partner were economically dependent on retaining the client; and (iii) a number of ex-Andersen staff worked for Enron and the relationship was believed to be too cosy. There were also concerns about how the firm managed its internal quality control $^{4}$ and its partner incentive mechanisms. In the US these issues and others associated with the 
systemic failure are being addressed through the provisions of the Sarbanes-Oxley Act, which was hastily passed in July 2002 to restore confidence in the US market (Sarbanes-Oxley Act, 2002).

In the UK the principal concerns in the public domain focused on calls for the rotation of audit firms and for the banning of non-audit service provision by incumbent auditors. Apart from a plethora of press comment, these issues were also raised by the House of Commons Treasury Committee (2002) and the chairman of the Financial Services Authority (Accountancy Age, 2002).

At the time of the Enron collapse, the Accountancy Foundation Review Board (Review Board), which came into operation in 2001, was responsible for oversight of the accountancy profession in the UK (Accountancy Foundation, 2002), including auditor independence. ${ }^{5}$ The Review Board therefore took the leading role in providing input to the auditor independence review. ${ }^{6}$ Both the chairman and the director of the Review Board were members of the CGAA. Although time was limited, the chairman and the Review Board were anxious to ensure that any decisions made by the CGAA about auditor independence should be evidence-based. The director was asked to establish a research programme to meet the principal concerns, focusing particularly on auditor rotation and the provision of non-audit services by incumbent auditors. Although there was little in the UK public debate about the other Enron concerns namely: audit quality control; partner reward structures; high levels of economic dependence (leading to fear of losing the client); and audit firm staff joining clients, these issues were of concern to the Review Board. The director, on behalf of the Review Board, commissioned research from leading academics and market researchers. Further studies were carried out in house. Other bodies also prepared or commissioned studies which were provided to the Review Board and to other interested parties. When all the research studies had been received, a further study was commissioned which consolidated the Enron concerns and the results of the research programme (and other relevant literature). The extant UK framework for auditor independence was reviewed in the light of the concerns and the research findings, and from this evidence recommendations for change were made. ${ }^{8}$ The results of the research and the recommendations were then submitted to the
$\mathrm{DTI}^{9}$ and fed into the CGAA's decision-making process.

This paper has two objectives. The first objective is to provide, for academic readership, the Review Board's recommendations for change to the UK auditor independence regime and the evidence which underpinned them. The second objective is to compare the auditor independence recommendations in the CGAA's final report, which have been accepted by the government, with the Review Board's recommendations in order to evaluate the extent to which the Review Board's evidence-based research underpinned public policy in this area.

The remainder of this paper is divided into four sections. The following section summarises the findings of the research commissioned by, or provided to, the Review Board during 2002. Then the Review Board's proposals for change are compared to the proposals in the CGAA's final report and the other related reports brought out at the same time. ${ }^{10}$ Conclusions are drawn in the final section.

\section{RESEARCH COMMISSIONED BY, OR PROVIDED TO, THE REVIEW BOARD DURING 2002 RELATING TO AUDITOR INDEPENDENCE}

The programme of research which underpinned the Review Board's independence recommendations is shown in Table 1. The programme covers the following topics: non-audit services; auditor rotation and competitive tendering; auditor changes; attitudinal surveys; differences between the public and private sectors; and the summary paper referred to above. As can be seen from the table, six of the ten studies were provided by independent academics. The Review Board was particularly interested in obtaining literature reviews and other research in the two key areas of non-audit services and rotation.

The results of the academic research and other evidence obtained by the Review Board is presented under the following headings: definitions of auditor independence; non-audit services and auditor independence; auditor changes; auditor rotation and competitive tendering; activities of the audit committee; issues from the comparison of practices in the public and private sectors; and the review of the UK regulatory framework for auditor independence in 2002. 
Table 1: Summary of research commissioned by, or provided to, the Review Board

\begin{tabular}{|c|c|c|c|}
\hline Topic & Title of study & Authors & Sponsor \\
\hline \multirow{2}{*}{$\begin{array}{l}\text { Non audit } \\
\text { services }\end{array}$} & $\begin{array}{l}\text { 1. Auditor independence and non-audit services: } \\
\text { a literature review }\end{array}$ & $\begin{array}{l}\text { Beattie and } \\
\text { Fearnley }\end{array}$ & ICAEW \\
\hline & $\begin{array}{l}\text { 2. The provision of non-audit services to audit } \\
\text { clients: independence and other issues } \\
\text { (a discussion paper) }\end{array}$ & $\begin{array}{l}\text { Canning and } \\
\text { Gwilliam }\end{array}$ & RB1 \\
\hline Auditor & 1. Mandatory rotation of audit firms & Not named & ICAEW \\
\hline \multirow[t]{2}{*}{ rotation } & 2. Mandatory auditor rotation: a summary & $\begin{array}{l}\text { Moizer and } \\
\text { Mohamed }\end{array}$ & $\begin{array}{l}\text { ICAEW \& } \\
\text { RB2 }\end{array}$ \\
\hline & $\begin{array}{l}\text { 3. The impact of mandatory audit rotation on } \\
\text { audit quality and on audit pricing: the case } \\
\text { of Italy }\end{array}$ & $\begin{array}{l}\text { Dallachio and } \\
\text { Vigano }\end{array}$ & ECG \\
\hline $\begin{array}{l}\text { Auditor } \\
\text { changes }\end{array}$ & UK listed company auditor changes in the 1990 s & $\begin{array}{l}\text { Moizer, Porter } \\
\text { and Mohamed }\end{array}$ & $\begin{array}{l}\text { ICAEW \& } \\
\text { RB3 }\end{array}$ \\
\hline \multirow[t]{2}{*}{$\begin{array}{l}\text { Attitudinal } \\
\text { surveys }\end{array}$} & $\begin{array}{l}\text { 1. A survey into the attitudes of audit clients, } \\
\text { auditors and institutional investors towards } \\
\text { audit issues }\end{array}$ & Mori & RB4 \\
\hline & $\begin{array}{l}\text { 2. Face to face interviews with auditors, audit } \\
\text { clients and institutional shareholders }\end{array}$ & Not named & RB5 \\
\hline $\begin{array}{l}\text { Public and } \\
\text { private sector }\end{array}$ & $\begin{array}{l}\text { An assessment of the possible application of the } \\
\text { public sector audit model to the UK private } \\
\text { sector }\end{array}$ & Not named & CIPFA \\
\hline $\begin{array}{l}\text { Summary and } \\
\text { recommendations }\end{array}$ & $\begin{array}{l}\text { Auditor Independence: the way forward in the } \\
\text { UK }\end{array}$ & Fearnley & RB5 \\
\hline
\end{tabular}

Key to sponsors: ICAEW - Institute of Chartered Accountants in England and Wales; RB - Review Board; ECG - European Contact Group (a body representing larger audit firms in Europe); CIPFA - Chartered Institute of Public Finance and Accountancy.

Key to academic authors: Beattie: University of Glasgow; Fearnley: University of Portsmouth Business School; Canning: Dublin City University; Gwilliam: London School of Economics and Political Science and University of Wales, Aberystwyth; Moizer and Mohamed: University of Leeds; Dallachio and Vigano: SDA Universita Bocconi; Porter: University of Wellington.

\section{Definitions of auditor independence}

Beattie and Fearnley provide a summary of definitions of independence from the regulatory frameworks of Australia (ICAA, 2002), UK (CAJEC, 1996), SEC (2000), Ontario (ICAO, 2002), IFAC (2001) and the EC Recommendation (EC, 2002). All the statements make a distinction between independence in fact and independence in appearance. The frameworks use the term independence of mind when referring to independence in fact and the term objectivity is generally preferred to independence. There is consensus that objectivity is a state of mind which is free of influences that compromise judgment and which has regard to all considerations relevant to the task, but no other. SEC (2000) recognises that such objectivity is difficult to prove except in unusual circumstances and is usually demonstrated by circumstantial evidence.

There is also general consensus on the definitions of independence in appearance. The definitions focus on the avoidance by the auditor of circumstances where a reasonable and informed third party (or public perception) would question the auditor's ability to act objectively. Interestingly, IFAC (2001) contains an expectation that the reasonable and informed third party should have 'knowledge of all relevant information, including any safeguards applied'. SEC (2000) is slightly different in restricting the third party to a 'reasonable investor with knowledge of all relevant facts and circumstances'.

Fearnley considers the two key attributes of audit quality which are necessary to avoid audit failure: competence and independence. 


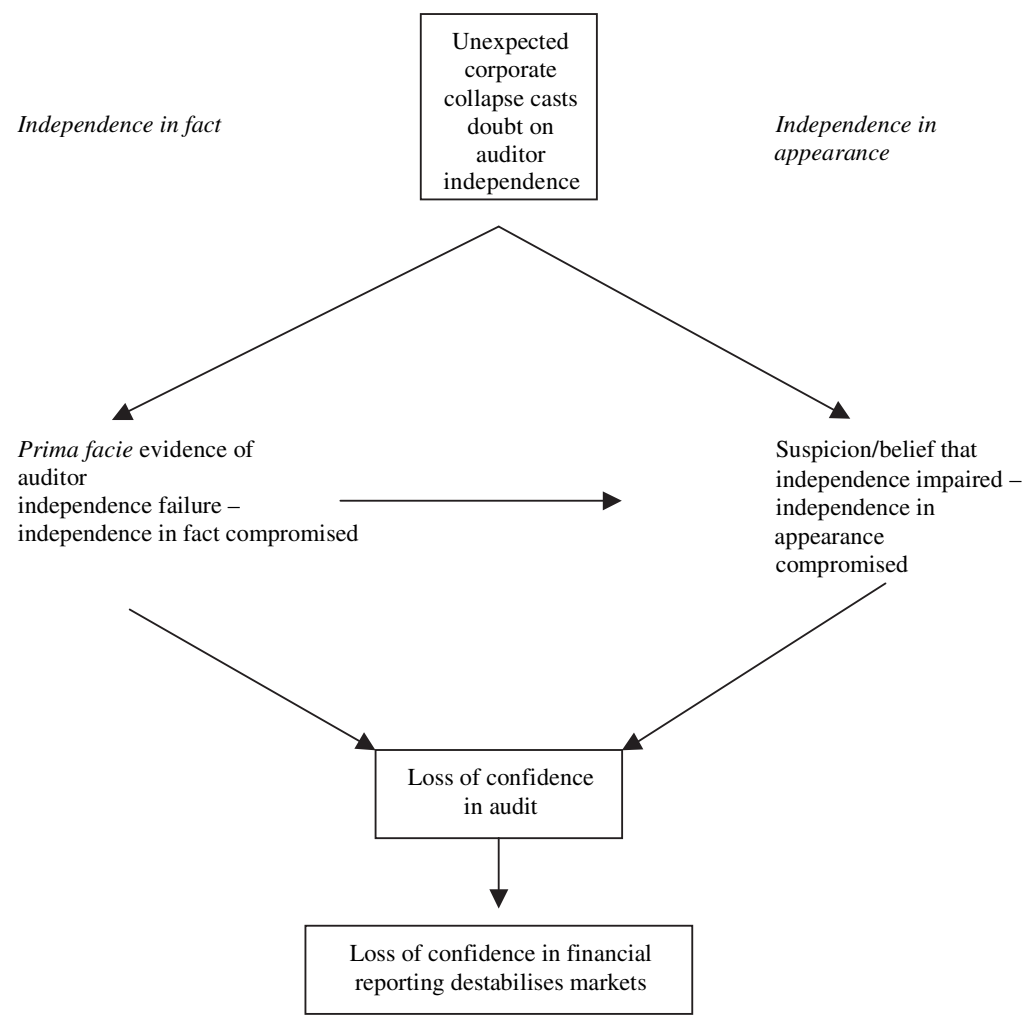

Figure 1: Relationship between independence in fact and independence in appearance

Competence means that errors, omissions and misstatements will be identified. Independence means that the auditor will ensure that management puts the problems right or, failing that, will qualify the audit report. She cites the remarkably prophetic seminal work by De Angelo (1981) who shows that an auditor who compromises quality in order to retain one client risks reputation damage which may lead to loss of income from other clients.

Fearnley further considers independence in fact and independence in appearance, showing diagrammatically how the two interrelate in the case of an unexpected corporate collapse which casts doubt on the quality of the audit.

As can be seen from Figure 1, the appearance of an independence failure is enough to undermine confidence in audit and financial reporting. Prima facie evidence of lack of independence in fact further undermines confidence. This emphasises the importance of independence in appearance because independent behaviour (i.e. independence in fact) is unobservable.
Fearnley cites recent relevant UK research, particularly the Beattie et al. (1999) study. By surveying UK finance directors, audit partners and financial journalists, they find that the key factors believed to threaten independence in the UK are: overall economic significance and status of the client to the partner, where personal income depends on client retention; overall economic significance and status of the client to the office and the firm; level of non-audit services $(100 \%$ of the fee is seen as being significantly more of a threat than $50 \%{ }^{11}$ ); and directors' de facto control of the audit appointment and the fee. The most influential factors enhancing independence are: audit committee with independent directors; rotation of partners; firm's quality control; the enforcement and penalty regime (the risk of loss of licence to audit and the risk of a Financial Reporting Review Panel $^{12}$ investigation rank highly); and protection from removal from office. Interestingly, the threats listed above are reflected in the criticism of Andersen in the Enron case. 


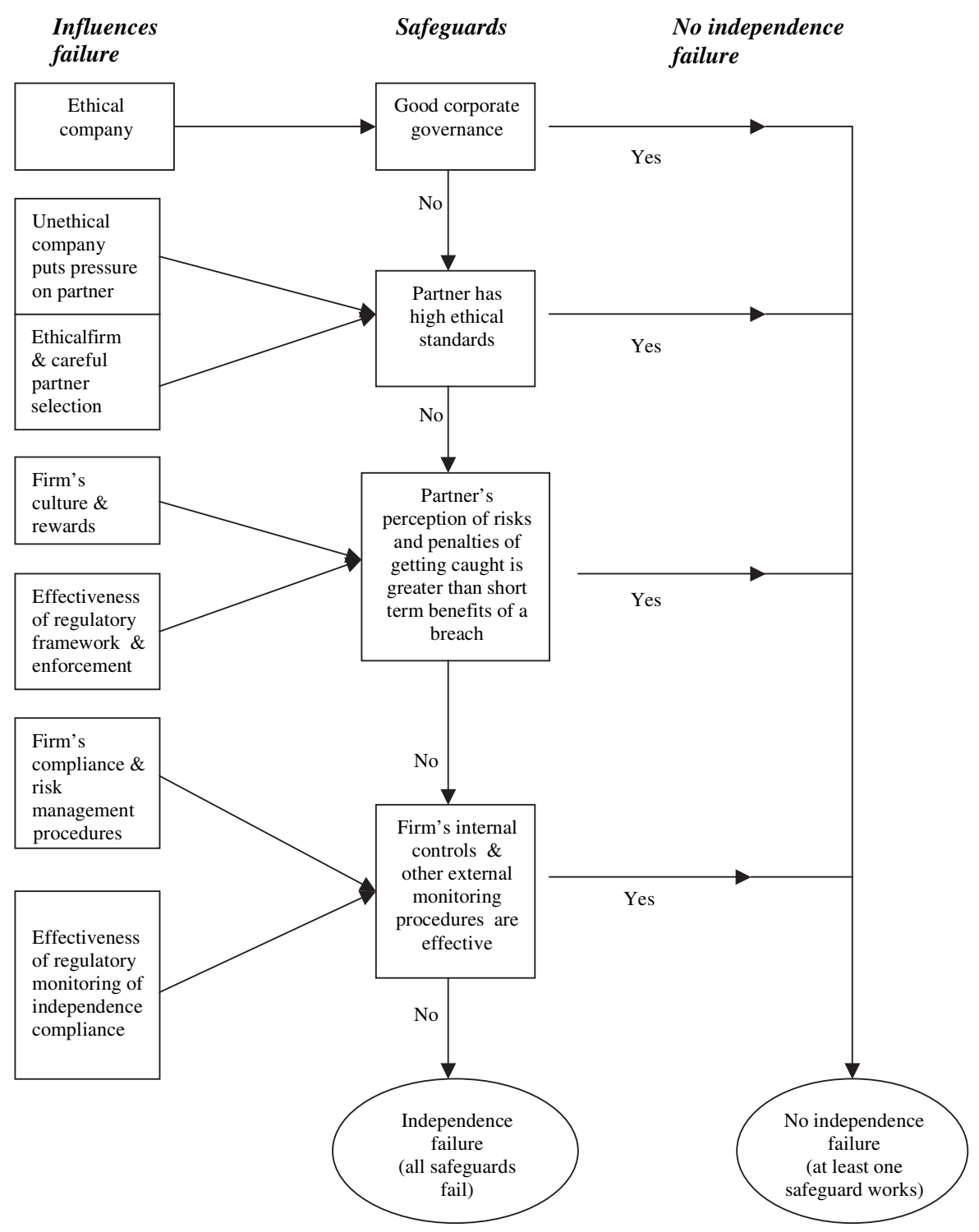

Figure 2: Chart of independence in fact

Fearnley also refers to UK and other country studies which recognise the significant influence that the ethical development of the individual audit partner and the ethical culture within a firm have on independent behaviour (Beattie et al., 2001; Kleinman \& Palmon, 2001). These influences and safeguards on independence in fact are presented in Figure 2.

Figure 2 shows that: (i) an ethical company with good corporate governance will not attempt to undermine auditor independence; (ii) a partner with high ethical standards will not give in to pressure; (iii) a partner with lower ethical standards will consider the strength of the regulatory framework, peer group pressure and the risks and personal penalties of getting caught before compromising independence; and (iv) an inappropriate in-firm reward structure is an incentive to take risks. The final backstop is the firm's internal quality control and the external 
monitoring procedures. Fearnley points out that very little is known about how the external auditor monitoring process works and how firms themselves establish and maintain ethical standards and quality control.

\section{Non-audit services and auditor independence}

In addition to the two studies which specifically focus on non-audit services and independence (Beattie and Fearnley; Canning and Gwilliam) three other studies (Mori; RB5; CIPFA) address aspects of the subject. The findings fall into five areas: fees and disclosure; perceived and actual threats to independence; the advantages and disadvantages of auditors providing non-audit services; international variations in regulatory policy; and the role of the audit committee in approving non-audit services.

Beattie and Fearnley report that by 2001 the level of non-audit services fees paid by the largest UK companies far exceeded the level of the audit fee. The ratio of non-audit to audit fees paid to the incumbent auditor rose from $98 \%$ in 1996 to $300 \%$ in $2001 .^{13}$ There was no requirement to disclose the breakdown of the composition of the fee between service types. Canning and Gwilliam and RB5 suggest more disclosure of the types of non-audit services undertaken by audit firms rather than a prescribed limit on the cost of those services. The Mori study finds belief that audit fees have been driven down because the audit service has become a loss leader for firms as it provides access to the more lucrative non-audit services market.

In considering the impact of non-audit services on auditor independence, Beattie and Fearnley point out that where audit and non-audit services are provided to the same company, two different contractual relationships exist. The non-audit services contractual relationship is with the company (as is the case with any other service provider) while the audit contractual relationship, though also with the company, requires in addition that the auditor owes a duty of care to the shareholders. Moreover, the audit is subject to regulatory oversight. However, the audit firm and the directors may perceive the purchase of audit in the same light as that of any other service and may not distinguish between audit and non-audit services, particularly in respect of services which are linked to the annual reporting round.
Beattie and Fearnley find that the provision of non-audit services presents wide-ranging threats to independence, encompassing attributes of four of the five threats ${ }^{14}$ identified in the UK independence framework. These are: self-interest fear of losing the client and the subsequent loss of income and status; self review - auditing one's own work or failing to review a previous defective decision; advocacy - taking an extreme position in acting on behalf of, or advising a client (possibly to the detriment of investors); and familiarity becoming too close to the client and identifying too closely with management objectives. Three studies indicate beliefs that the provision of non-audit services undermines the appearance of auditor independence (Beattie and Fearnley, Canning and Gwilliam, and Mori). Mori identifies concerns that independence may be compromised by the audit firm's desire to retain access to the more lucrative non-audit services and concerns that partners' income and promotion prospects may be linked to the level of non-audit services provided to audit clients. However neither Beattie and Fearnley nor Canning and Gwilliam find conclusive evidence from academic research that non-audit services provision undermines independence in fact, although it is recognised that this is difficult to measure as the audit process itself is not publicly observable, nor are the procedures for quality control and ethical standards within the firms.

Beattie and Fearnley summarise studies that show there are efficiencies in the joint provision of audit and non-audit services arising from knowledge spillovers and contractual economies of scope. They find little evidence that joint provision reduces cost but there is evidence that restrictions on joint provision would increase costs for companies and audit firms. Canning and Gwilliam take the view that if the quality of audit per se is more important to the workings of capital markets than the joint provision of audit and nonaudit services, then the benefits of joint provision have to be unequivocally demonstrated.

Regulatory frameworks ${ }^{15}$ are found by Beattie and Fearnley to differ in terms of the permissibility and disclosure requirements for non-audit services. Related to this, Canning and Gwilliam believe that categorisation of permitted and nonpermitted services in line with the SEC rules is fraught with difficulty.

Three studies (Mori, RB5 and CIPFA) see an enhanced role for audit committees in the approval 
of non-audit services. Mori finds views that audit committees should be responsible for the allocation of non-audit services. RB5 argues that the principles for awarding non-audit services should be set out in the Combined Code and the policy disclosed in the company's annual report. CIPFA suggest that permission should be obtained from the audit committee to exceed a threshold value for non-audit services.

These studies provide clear evidence that the provision of non-audit services, particularly at a significant level, undermines independence in appearance and threatens the credibility of audit. The research does not point to the need for a total ban on the provision of non-audit services. The appearance problem indicates a need for the following information: more transparency about how firms manage the conflicts of interest that NAS provision creates; whether audit partners are rewarded for earning NAS; and the nature of the NAS being provided. There is also evidence of a desire to see the company audit committee approving the provision of NAS.

\section{Auditor changes}

Moizer, Porter and Mohamed find 609 changes of listed company auditor between 1990 and 2000, which is equivalent to an annual rate of change of $2.25 \%$. This indicates a relatively low rate of auditor change and, if audits were changed evenly throughout time, it would take approximately 45 years before all audits were changed. The Big Six (i.e. the top tier before the PricewaterhouseCoopers merger and the collapse of Andersen) were the incoming auditor for $68.8 \%$ of the changes and outgoing auditor for $55.8 \%$ of the changes. This shows a steady rise in the market share of the big firms in this sector.

Moizer et al. also find that the vast majority of companies changing auditors received an unqualified report before the change. There were relatively few qualified reports for companies after an auditor change and there was little difference between old and new audit firms in terms of qualified reports. They conclude that it is impossible to make any sensible inferences about the reasons for an auditor change from published information, because there is either no information at all or the information given provides no clues as to what happened. This research points to a need for review of the auditor appointment and change process.

\section{Auditor rotation and competitive tendering}

Three studies focus specifically on auditor rotation: a study prepared by the ICAEW; Moizer and Mohamed's summary of the academic literature on rotation; and a study of the Italian market by Dallachio and Vigano. RB5, Mori and CIPFA also report on rotation and Mori and RB5 comment briefly on competitive tendering in the UK.

Arguments for and against auditor rotation are identified in the studies. Moizer and Mohammed find, on balance, that the academic literature favours the arguments for mandatory rotation rather than the arguments against it. Moizer and Mohamed do not suggest that there will be a massive improvement in the quality of an audit, rather that there will be a net positive improvement, because mandatory rotation of audit appointments is likely to reduce the probability of a large scale independence-related audit failure. The ICAEW study argues that perceived benefits of mandatory rotation are: an improvement in audit quality due to the avoidance of overfamiliarity with the client and its management; the opportunity for a fresh approach to the audit; a better perception of auditor independence; and the benefits of competition.

However there is much argument against rotation from a practical perspective. RB5, Mori and ICAEW find that the learning curve in the early years of an audit and the implications of rotation for audit costs, quality and the risk of audit failure are the most widely cited reasons for this opposition. ICAEW finds concerns about start up costs for companies and audit firms and concerns that a lack of incentive to maintain quality could arise where an audit is about to change hands. Signals that may be given out currently when there is a change of auditor will be lost. In addition, the small number of large audit firms leads to lack of choice because of conflicts of interest, both at firm and partner level. Also the rules restricting firms' partners and staff from holding financial interests in clients would force partners and staff regularly to change their investment portfolios, an unattractive prospect (ICAEW, RB5). As the annual rate of auditor change in the period from 1990-2000 averaged $2.25 \%$ (Moizer and Mohamed) mandatory rotation would cause many more companies to incur the costs and disruption of enforced change. Although mandatory rotation is a feature of some public sector audit appointments, ${ }^{16}$ because of the costs 
and the limited choice of firms, CIPFA does not consider implementation of rotation in the private sector is practical. Regulatory reviews in Australia and the Republic of Ireland concluded that, in balancing the arguments, the costs of mandatory rotation outweighed the benefits (ICAEW).

Italy is currently the only EU country where rotation is mandatory. Rotation applies every nine years with compulsory competitive tendering every three years. Dallachio and Vigano find that the mandatory audit rotation rule constitutes a potential mechanism to improve auditor independence but they believe that it risks being simply a 'theoretical' solution to the problem which in practice carries significant risks. They find that the current rule seems to have intensified price competition. In the case of auditing, which is generally considered a public interest activity, this could be considered as inappropriate. This is even more so if growth in competitive pressure in the audit market exceeds the ability of the governance and professional ethics culture to cope. They suggest that regulators could concentrate on the following mechanisms: rotation of engagement partners within the firm; the role of the second partner and of internal control and governance mechanisms in audit firms; peer review among auditors in the firm, between audit firms and by professional bodies; and supervision by regulators.

Dallachio and Vigano also recommend that audit fees should never drop below the minimum fee threshold that permits audit activities to be carried out adequately, both in terms of quality and timing, especially considering the complexity of appointments. This is in line with a common conviction from the professional world that the pillars for quality in professional activities (of public interest) can be traced to: professional standards; quality control mechanisms; and minimum fees for services. They also find that, in Italy, financial markets seem more interested in the quality of the audit process than in mandatory rotation.

RB5 and Mori show beliefs that competitive tendering has reduced audit fees, forced out waste and made firms focus on risk. There are also beliefs that audit quality may have suffered as a result of lower fees.

These studies show that while audit firm rotation is perceived, in theory, to enhance auditor independence, the practical problems associated with its introduction are such as to make it undesirable. The Dallachio and Vigano research into the experiences in Italy is particularly telling. They recommend the alternative regulatory mechanisms of partner rotation, quality control within firms, peer review and regulatory supervision.

\section{Activities of the audit committee}

Apart from involvement in the approval of NAS, the following roles for the audit committee are supported: recommending the appointment of the auditors (Mori and RB5); the setting of the remuneration of the auditors (Mori and RB5); the review of auditor independence (Mori and RB5); the evaluation of audit effectiveness (Mori and RB5); communicating with the auditors (Mori and RB5); and a more public approach to audit reporting, whereby the audit committee reports in the company's annual report on how the company has responded to the auditors' findings and recommendations (CIPFA).

\section{Issues from the comparison of practices in the public and private sectors}

CIPFA suggests that, with due consideration to practical and legal problems, the following practices adopted in some areas of the public sector merit further consideration to assist the effectiveness of private sector audit. These are: the establishment of a central body to which auditors can turn for authoritative advice on legal, accounting or audit related matters or to which significant suspicions or concerns could be reported; co-operation and exchange of information between auditors during audits and the in-depth exchange of working papers and audit knowledge on change of auditors (this suggestion is particularly vulnerable to litigation constraints); a legal requirement for companies to appoint a chief financial officer who is a qualified member of a recognised accountancy professional body; a statutory right for auditors to obtain information relevant to their audits from any source; and publication of the results of independent quality control reviews to inform the appointments made by the audit committee.

The CIPFA paper raises some different issues but that there is common ground with the other studies on concerns about auditor change and the transparency of firms and the regulatory process. 


\section{Review of the UK regulatory framework for auditor independence in 2002}

Fearnley summarises and reviews the 2002 UK auditor independence framework taking account of the Enron concerns and the findings of the Review Board's research programme. Independence related regulations are found to derive from four separate sources: the professional ethical guidelines (including auditor independence guidelines) which were developed by the Chartered Accountants Joint Ethics Committee (the CAJEC framework, 1996); ${ }^{17}$ company law; auditing standards set by the Auditing Practices Board; and the Audit Regulations (ICAEW, 1995). ${ }^{18}$

Table 2 summarises the independence provisions from the CAJEC framework, (as updated by the 2002 EC Regulation). The framework identifies a series of threats to independence together with the safeguards which can be put in place to reduce the independence risk to an acceptable level. Where it is believed that the independence risk cannot be safeguarded, the framework contains a prohibition. Also included are two legal provisions. Section 27, Companies Act, 1989, prohibits certain parties from acting as auditor, and Sections 390A and B require disclosure in the company's annual report of audit fees and NAS.

The summary of the CAJEC framework highlights some deficiencies. There are no explicit safeguards against five key independence threats. (The absence of a safeguard is shown as 'none' in bold type in the column headed 'Safeguards' in Table 2) These five threats are: the fear of losing a client; reviewing previous judgments or decisions taken about the performance of the audit; supporting the clients' interest; adopting an extreme position on tax or other matters; and intimidation.

A surprising provision is that an auditor may have a listed company client which provides up to $10 \%$ of a firm's income. Although second partner reviews are required where income is more than $5 \%$ or where the individual office is economically dependent on a client, this is a high level of economic dependence. Also, although there is a Companies Act requirement for the amount of NAS to be disclosed, there is no requirement in the 2002 framework to indicate the nature of the services which the audit firm provides. Finally, although the self review threat refers to the problem of the auditor reviewing his or her own work, the safeguard is restricted to a limited list of prohibited NAS. Some of the key NAS concerns are not fully addressed.

Table 3 summarises the provisions of the regulatory framework other than the CAJEC ethical guide. These provisions set out the procedures that an audit firm is required to follow in order to maintain competence and independence and are found in the Audit Regulations (ICAEW 1995), Statements of Auditing Standards and company law. Table 4 contains other provisions which influence auditor independence less directly. These are related to corporate governance, conduct of directors, reputation loss and liability.

These tables identify further deficiencies in the overall regulatory framework. The Audit Regulations and Auditing Standards are prescriptive in their requirements for quality control within the audit firm, but do not refer to partner reward structures. More generally, there is no requirement for firms to make any information available to investors, company managers or other stakeholders about the audit process and how they maintain audit quality and independence. Thus, apart from the firm itself, only the Recognised Supervisory Body responsible for the monitoring of the audit firms knows how the firms operate in order to achieve a satisfactory level of independence and compliance. This is difficult to reconcile with the generally accepted definitions of independence in appearance which assume an informed investor or other user. It is unclear where they would get their information from.

There are also identifiable deficiencies in the corporate governance recommendations and the law relating to the conduct of directors. The Combined Code is weak in its expectations that a company audit committee will take the lead in recommending appointment and remuneration of auditors to the members, and will be involved in the agreement of the NAS to be provided by the audit firm. Company law requirements are also limited in their expectations of directors on change of appointment. Whereas the auditor is required by the CAJEC guidelines to communicate with the previous auditor, the directors are able to withhold consent for this communication to take place. There is also very little in company law which requires the directors to co-operate fully with the audit process. ${ }^{19}$ 
Table 2: Summary of UK threats and safeguards ethical framework including EC Recommendation (2002)

$\begin{array}{lll}\text { Threats } & \text { Safeguards } & \text { Regulatory } \\ \text { source }\end{array}$

1. Self interest or other conflict of interest

1a. Financial interest in client performance

Direct or indirect financial interest in a client;

contingency fees; loans; overdue fees; mutual

Generally prohibited for partners, staff and firm.

EG

Ecss interest with a clien

1b. Economic dependence

Undue dependence on a client, for firm, office

or partner, including non-audit services.

No more than $10 \%$ total fees (including non-audit services) from one listed or public interest client (15\% others). Where income $>10 \%$

EG

for any client or $5 \%$ for listed or public interest client or where

office dependent on one client, second partner, or possibly other

firm review required.

Disclosure of audit fees and non-audit services in company annual

report.

Low-balling.

Fear of losing a client.

1c. Involvement with the affairs of a clien

Participation in the affairs of a client.

Firm must be able to demonstrate maintenance of standards.

\section{None.}

S.390A,B. CA

1989

EG

None

Auditor cannot be officer or employee of company, or partner or employee of such; Auditor should not have close family in company. Partner prohibited from joining client within 2 years.

Partner or senior employee joining client.

Provision of other services to audit clients. reviewed.

Activities normally prohibited:

preparation of accounts and accounting records for public interest $\quad$ ECR

companies;

exercising management authority (through non-audit services);

recruiting senior management;

provision of expert services affecting material amounts or disclosures;

S.27,CA1989

EG

$\mathrm{ECR}$

EG

Activities restricted:

providing IT and financial information and technology systems very

EG restricted;

internal audit restricted;

litigation support restricted.

ECR

ECR

ECR

ECR 


\section{Table 2: Continued}

\begin{tabular}{lll}
\hline Threats & Safeguards & Regulatory
\end{tabular}

1d. Other conflicts: potential litigation;

excessive hospitality.

2. Self review threat

2a. Reviewing own work re non-audit services

$2 b$. Reviewing previous judgments or decisions

re performance of audit

3. Advocacy threat

3a. Supporting client's interests

$3 b$. Sharpened form of advocacy

Recommending or promoting shares.

Leading a corporate finance team.

Adopting extreme position on tax or other

matters.

4. Familiarity or trust threat

4a. Being drawn by familiarity into taking

management decisions

4b. Acting for a prolonged period of time

5. Intimidation threat

Normally prohibited.

source

Key: EG = ICAEW ethical guide 1.201 (issued 1997)

See 1c above for prohibitions and restrictions.

None.

ECR

None

None (other than judgment).

EG

Prohibited

Prohibited.

\section{ECR}

ECR

None (other than judgment).

Taking management decisions prohibited.

(e.g. Auditor should not act as actuary for insurance company.)

Ensure management takes responsibility for advice given by auditor

Partners to be rotated every seven years and not return for two years.

None.

EG

$\mathrm{EG}$

EG

EC

None

ECR = European Commission Recommendation (2002): Statutory auditors' independence in the EU: A set of fundamental principles

$\mathrm{CA}=$ Companies Act requirement. 
Table 3: Summary of detailed audit firm procedures required in the UK to maintain auditor competence and independence

1. Leadership and responsibilities

Firms should establish and communicate quality control practices and policies; appropriate structure should be

established; senior audit partner (compliance partner) should take responsibility. Internal monitoring should take place annually.

2. Acceptance and continuation of audit engagements

2.1 Before accepting a new audit engagement firms should ensure that: they are competent; any threats to independence can be adequately safeguarded; they have assessed the integrity of owners, directors and management.

2.2 A registered auditor must not accept an appointment or continue as an auditor if the firm has any interest likely to conflict with carrying out the audit properly.

2.3 Matters should be reconsidered each year on re-appointment.

2.4 The auditor is appointed every year by the members at the AGM.

2.5 Before accepting appointment the auditor should communicate with the existing auditor and the latter should reply promptly as to any considerations which might affect the prospective auditor's decision whether or not to accept appointment. Appointment should not be accepted if the client withholds permission to talk to the previous auditor.

3. Leaving office

3.1 If firms become aware of any factors which would have caused them to decline the appointment, they should consider whether to complete the current audit or whether to resign.

3.2 An auditor should make a statement of circumstances connected with his ceasing to hold office which he considers should be brought to the attention of the members or creditors of the company, or, if he considers that there are no such circumstances, a statement that there are none.

3.3 A company must send to the auditor a copy of any notice of a resolution to remove the auditor from office. The auditors are entitled to make written representations for distribution to the members, who must be informed that representations have been received. The company must distribute the representations before the meeting if there is time. This may also be prevented by the court if the material is defamatory. However the auditors may still make representations at the AGM.

4. Resources and quality

4.1 Firms should have sufficient partners and audit staff with competencies necessary to meet their needs. Firms should assign audit staff with the competencies necessary to perform the audit. Competencies include: understanding and experience of auditing; understanding accounting, auditing, ethical and other technical standards; specific industry knowledge; professional judgment; understanding quality control procedures and processes. Competence must be maintained.

4.2 A registered auditor must make arrangements so that all principals and employees maintain the principles of independence and confidentiality set out in the ethical statements.

4.3 Audit engagement partners should ensure that work is directed, supervised and reviewed in a manner that provides reasonable assurance that the work has been performed competently. 


\section{Consultation}

5.1 Firms should establish procedures to facilitate consultation and to ensure that sufficient resources are available to enable consultation to take place in relation to difficult or contentious matters within or without the firm. The results should be documented.

6. Fit and proper status of staff and partners

6.1 A registered auditor must make arrangements so that each principal and anyone the firm employs to do audit work is and continues to be a fit and proper person.

7. Improper influence

7.1 A registered auditor must make arrangements to prevent anyone who is not a responsible individual from having any influence which would be likely to affect the independence or the integrity of the audit.

8. Independent review

8.1 Firms should ensure that an independent review of listed, public interest or high risk clients is undertaken before the audit report is issued. The review should include (among other issues): objectivity of partner and staff; effective risk analysis and planning; and judgments made.

8.2 Procedures should be in place for dealing with conflicting views between audit team members, partners and the independent review partner.

9. Communication with audit committee (or others charged with governance)

9.1 Auditors should communicate relevant matters relating to the audit of the financial statements to those charged with governance of the entity. Such communications should be on a sufficiently prompt basis to enable those charged with governance to take appropriate action.

9.2 At least annually ... (for listed companies), the auditors should disclose in writing and discuss as appropriate: all relationships between the audit firm and its related entities and the client entity and its related entities that may reasonably be thought to bear on the firm's independence and the objectivity of the audit engagement partner and the audit staff; the safeguards that are in place; and confirm in writing that, in their professional judgment, the firm is independent within the meaning of regulatory and professional requirements and the objectivity of the audit engagement partner and the audit staff is not impaired.

9.3 Auditors should communicate with those charged with governance: expected modifications of the audit report; unadjusted misstatements; material weaknesses in the accounting and internal control systems identified during the audit; their views about the qualitative aspects of the entity's accounting practices and financial reporting, matters specifically required by other Auditing Standards to be communicated to those charged with governance; and any other relevant matters relating to the audit.

9.4 Auditors should seek to obtain a written representation from those charged with governance that explains their reasons for not adjusting misstatements brought to their attention by the auditors.

$\mathrm{AR}=$ Audit Regulations and Guidance (ICAEW 1995)

$\mathrm{CA}=$ Companies Act 1985 .

SAS = Statement of Auditing Standards issues by the Auditing Practices Board. 
Table 4: Safeguards not referred to elsewhere in the UK regulatory framework

\begin{tabular}{|c|c|c|}
\hline $\begin{array}{l}\text { Type of } \\
\text { safeguard }\end{array}$ & Description & Source \\
\hline $\begin{array}{l}\text { Within the } \\
\text { company }\end{array}$ & $\begin{array}{l}\text { 1. Duties of the audit committee should include keeping under } \\
\text { review the scope and results of the audit and its cost effectiveness } \\
\text { and the independence and objectivity of the auditors. Where the } \\
\text { auditors also supply a substantial volume of non-audit services } \\
\text { to the company, the committee should keep the nature and extent } \\
\text { of such services under review, seeking to balance the maintenance } \\
\text { and objectivity with value for money. }\end{array}$ & $\begin{array}{l}\text { Combined Code } \\
\text { (para. D.3.2) }\end{array}$ \\
\hline Within the & 1. Risk of litigation. & Market or possible \\
\hline firm & $\begin{array}{l}\text { 2. Risk of loss of reputation and loss of clients (and possible } \\
\text { collapse) from corporate collapses where poor quality audit is } \\
\text { suspected. }\end{array}$ & regulatory action \\
\hline Within the & 1. Criminal offence for directors to mislead an auditor.* & Companies Act \\
\hline regulatory & 2. Risk of being found out by Joint Monitoring Unit or Review & Audit regulations \\
\hline framework & Possibility of losing licence or suffering reputation damage. & Review Panel \\
\hline
\end{tabular}

*The Company Law White Paper (Modernising Company Law, 2002) includes provisions for directors to be criminally liable for failure to disclose significant information to auditors.

In addition to the deficiencies arising in specific areas of the independence framework, the above analysis clearly shows that the responsibility for promulgation of the independence regulatory framework is fragmented with no single body having overall responsibility.

This review shows the necessity for a review of the current UK framework for independence in order that key threats to independence can be more explicitly addressed. The independence regime is found to be fragmented and the need for transparency in how audit firms operate is reemphasised. Further concerns arise about the regime for auditor re-appointment and change.

\section{HOW THE REVIEW BOARD'S EVIDENCE-BASED RECOMMENDATIONS COMPARE TO THE CGAA'S FINAL REFORMS}

In determining the proposals for change the Review Board considered the cost benefit and potential effectiveness of three different forms of regulatory change: voluntary compliance and transparency; extension of the regulatory framework; and increased enforcement. The recommendations focus on three main sources of safeguard against independence threats: safeguards within the company; safeguards within the audit firm; and safeguards within the regulatory framework.

\section{Proposal for change within audit firms}

The research clearly indicates the need for greater transparency from audit firms. It is impossible for an investor to be well-informed, as the definitions of independence in appearance demand, if essential information is not available. Specifically, the Review Board recommends that audit firms should disclose the following information: management structures; ethical standards; quality control procedures for audit and maintenance of independence; management of economic dependence at firm and partner level; and financial information about the relative profitability of audit and NAS. This would particularly enhance the appearance of independence.

\section{Proposals for change within companies}

The research indicates a need for disclosure of the breakdown of NAS bought by the company from its auditor, a wider role for the company audit committee in managing the relationship between the company and the auditor, and the inclusion in a company's annual report of a report on the audit committee's activities.

The Review Board recommends that a company audit committee should take responsibility for leading the following activities in respect of the company's relationship with the auditor: the annual appointment process; the adequacy of the 
fee; approval of NAS; changing auditors; and ensuring audit effectiveness and independence from the company's point of view. A report on these activities should be included in the company's annual report. ${ }^{20}$ It is also recommended that more detailed disclosure is made in company accounts about the nature of the NAS bought by the company.

A wider role for the audit committee would enhance independence in that the audit committee provides a buffer between the auditor and the executive management, and the audit committee would also oversee independence issues from the company's perspective. Independence in appearance would be enhanced by the disclosures in the audit committee report and the breakdown of NAS.

\section{Proposals for change within the regulatory framework}

The research does not, on balance, support the introduction of mandatory rotation of audit firms. There are widespread concerns about the impact on the appearance of independence caused by the provision of NAS. Other issues which emerge from the research are: the fragmentation of responsibility for the regulatory regime for independence; doubts about the effectiveness of the appointment and change process; the permissible level of economic dependence of a firm on one client; and the effectiveness of the monitoring regime in respect of auditor independence.

The Review Board does not recommend mandatory rotation of audit firms or compulsory competitive tendering because of concerns about cost, market disruption and quality risks associated with both.

In respect of NAS the Review Board makes two recommendations. First, that an additional prohibition be brought into the independence framework that auditors should not give advice to management which is detrimental to the interests of investors. Second, that the range of permissible NAS should be reviewed to consider the continuing acceptability of services where the threats to independence are high, because of the firm auditing its own work, acting as an advocate for the client or getting too close to management.

The Review Board makes four further recommendations for change. First, responsibility for the UK auditor independence framework should be vested in the Auditing Practices Board, in preference to the 2002 fragmented regime, which is found to be deficient in several key areas, such as fear of losing the client and intimidation. Second, the permitted level of economic dependence for one audit client should be reduced to $5 \%$ of total practice fees. Third, a wide ranging review could be undertaken on the change of appointment procedures, which are also fragmented and which the research suggests may be ineffective in some areas. Fourth, the audit monitoring regime could take a wider role in reviewing independence in firms, particularly in relation to the management of economically significant clients. More comprehensive public reporting by the monitoring units would also help to inform investors and stakeholders of the extent of monitoring which already takes place.

\section{Changes to the UK auditor independence framework which were introduced by the government reviews}

The CGAA was established in February 2002 and issued two reports. An interim report was issued in July 2002 (CGAA, 2002) and the final report was issued in January 2003 (CGAA, 2003). The interim report envisaged: an enhanced role for audit committees by developing the existing Combined Code guidance, including making recommendations on the appointment of auditors; further work on the acceptability of certain types of NAS; an examination of the case for mandatory audit firm rotation; an extension of existing requirements to rotate audit partners; and transparency of audit firms.

By the time the CGAA interim report was issued (CGAA, 2002) the research programmes commissioned by the Review Board and other bodies were already in progress and the Council of the ICAEW had agreed to adopt the EC Recommendation (2002) on auditor independence. The EC recommendation suggests rotation of all partners engaged with the audit every seven years, but following the issue of the CGAA interim report, ICAEW and ICAS agreed to introduce a requirement that the audit engagement partner should rotate every five years. Also following the CGAA interim report, two further inquiries were set up. In September 2002, at the CGAA's request, the FRC set up a group under Sir Robert Smith to 
develop the existing guidance for audit committees contained in the Combined Code, which reported in January 2003 (FRC, 2003). Also in her oral statement which accompanies the issue of the CGAA interim report, the Secretary of State for Trade and Industry announced an immediate review of the regulatory arrangements for the auditing and accounting professions. A consultation document was issued by the DTI in October 2002 (DTI, 2002) and the final report (DTI, 2003) was issued in January. (In addition to these reports the review of the role and effectiveness of non-executive directors, set up in February 2002 and led by Derek Higgs, was published in January 2003 (Higgs, 2003)).

The recommended package of changes from these various reports is summarised in Table 5. The table shows the source of the recommendations and whether the changes coincide in principle with Review Board's recommendations. The changes are grouped into changes within companies, changes within audit firms and changes to the regulatory framework.

There are three principal differences between the Review Board's recommendations and the government reforms. The first is the disclosure by firms of fees in excess of 5\% received from any one client. The Review Board recommended an upper limit of $5 \%$ for fees from any one client. The CGAA was concerned that a prohibition could create a barrier to entry to the larger company audit market for firms other than the largest (CGAA, 2003, p. 37).

The second difference is the decision to set up a new unit to monitor listed and public interest companies separate from the professional bodies who currently operate the scheme through the Joint Monitoring Unit. The new unit will belong to the new Professional Oversight Board for Accountancy (POBA) under the Financial Reporting Council. The Review Board did not put forward this suggestion, but was not opposed to it in principle.

The DTI acknowledges that the decision to create this new unit was influenced by some respondents to the consultation paper on the Review of the Regulatory Regime of the Accountancy Profession (DTI, 2002), particularly the Financial Services Authority, and by international developments (DTI, 2003, pp. 40-41). It is believed that this change will put the independence of the process beyond doubt and retain the UK's position at the leading edge of best practice around the world (DTI, 2003, p. 41). However, responsibility for the licensing and discipline of auditors remains with the accounting bodies. This is the most organisationally complex and potentially the most costly change which the government has introduced in relation to auditor independence.

The third difference is that Review Board's recommendations for a review of the regulatory framework for auditor change has not been followed up. (The review of the permissable nonaudit services is left to the APB to address as part of its role in taking responsibility for setting standards for auditor independence. ${ }^{21}$ )

It is also interesting to note that the proposals in the CGAA report in relation to auditor independence are compatible, in a UK context, with the proposals Volker made for the changes to Andersen's practices in the US (see note 4).

\section{CONCLUSION}

This paper considers the impact of the Enron collapse on the regulatory framework for auditor independence in the UK, and describes a key aspect of the process which led to the changes to the UK's regulatory regime for auditor independence. The research programme, developed by the Accountancy Foundation Review Board and supported by input from other bodies, identifies areas where improvements could be made to enhance both independence in appearance and independence in fact. Although the Review Board's recommendations were not the only input to the reform process, it is found that recommendations made by the Review Board in respect of auditor independence align closely with the changes which were finally introduced.

Responsibility for the setting of auditor independence standards is transferred to the Auditing Practices Board (under the Financial Reporting Council). The company audit committee is expected to take a leading role in managing the relationship between the company and the auditor. The principal form of the changes is increased transparency and disclosure by audit firms, companies and regulators who monitor audit firm performance. The decision has been taken by government to encourage voluntary compliance and disclosure wherever possible in preference to more costly and interventionist strategies. However, further change is possible if these mechanisms prove unsatisfactory. 
Table 5: Summary of government reforms for auditor independence

Responsibility
for additional
reform

Report source

Principle

included in

Review Board

suggestions

Company The terms of reference of the audit committee should include:

Auditor appointment

Making recommendations to the board in relation to the appointment of the external auditor and approving the remuneration and terms of engagement of

the external auditor.

Auditor independence and effectiveness

Monitoring the external auditor's performance, independence and objectivity

taking into consideration relevant UK professional and regulatory

requirements.

Non-audit services

Developing and implementing policy on the engagement of the external auditor to supply non-audit services.

The audit committee ... in principle should not agree to the auditor providing the service if, having regard to the ethical guidance, the result is that the external auditor: audits its firm's own work; makes management decisions for the company; is put in the role of advocate for the company; or a mutuality of interest is created.

Listed companies should disclose in more detail in their annual report the information they give about non-audit services provided by their statutory auditor. (This requires legislative change.)

Report on audit committee activities

The annual report should contain a separate section that describes the role and responsibilities of the committee and the actions taken by the committee to discharge those responsibilities.

In respect of external auditors, the report should: describe the procedures adopted to review the independence of the external auditors, including disclosure of the policy in provision of non-audit services and an explanation of how the policy protects auditor independence; describe the oversight of the external audit process and confirm that an assessment of the effectiveness of the external audit process was made; explain the recommendations to the board on the appointment of the auditors and, if applicable, the process adopted to select the new auditor.

Audit firm Audit firm transparency

Audit firms with listed and public interest clients should disclose the fees received from a client where these exceed 5\% of the firm's total fees, and make the audit committee aware of the level of economic dependence.

Audit firms should make available information on their policies, procedures and processes for managing auditor independence within the firm, together with relevant management and reward structures, and management and financial information. Reports will initially be voluntary but will be statutory if they are judged inadequate after the first round for periods on or after 1 January 2003

CGAA p. 10

Yes

CGAA p. 12 \&

Yes Smith

CGAA p. 34 citing

Yes Smith

CGAA p. 35

Yes

CGAA p. 12

Yes

Smith pp. 33-34

Yes

CGAA pp. $11 \& 37$

No. RB

suggested

upper limit of

fee to be $5 \%$

from one client

CGAA pp. $11 \& 13 \quad$ Yes 
Regulators Mandatory rotation of audit firms and compulsory re-tendering

Mandatory rotation and compulsory re-tendering is not supported.

Standard setting for auditor independence

Responsibility for setting standards to uphold auditor independence should

be transferred to a body independent of the accountancy bodies.

The Auditing Practices Board should take over the professional bodies'

responsibility for setting standards for independence, objectivity and

integrity of auditors.

Non-audit service

Whilst there is little clear support for the view that joint provision has in fact

compromised auditor independence, it undoubtedly raises significant

concerns as to the appearance of independence.

The standard setter (i.e. the Auditing Practices Board) should further restrict the

circumstances in which auditors are able to supply internal audit services.

The standard setter should carefully review the circumstances in which it

is permissible to provide... valuation services, taxation services, and the

\section{Regulators \\ design and supply of IT and financial implementation technology systems. \\ Economic dependence on an audit client}

The standard setter (i.e. the Auditing Practices Board) for auditor

independence should develop improved qualitative guidance for audit firms

to ensure that auditors are alert to the threats to their independence arising

from the fear of losing an economically significant client at the level of the

audit firm, the office or the individual partner.

Enforcing auditor independence requirements

The Unit responsible for monitoring the work of auditors with listed

company clients should annually (i) publish information on how it

monitors auditor independence requirements and (ii) give aggregate

information on the effectiveness of the management of auditor

independence issues in the major firms.

Ownership of the monitoring unit

The FRC should take on the functions of the Accountancy Foundation

(including the Review Board), creating a new body, referred to in this

report as 'the independent regulator.'

A new audit inspection unit should take over from the professional

bodies responsibility for monitoring the audit of those entities whose

activities have the greatest potential to impact on financial and economic

stability-specifically, listed companies, major charities and pension funds.

It would report to the successor board to the Review Board. The new

unit should put a greater emphasis on judgments taken by auditors of

these companies rather than on their processes and systems.

Key to report sources:

$\vec{\forall}$ CGAA: Co-ordinating

group on audit and accounting issues: Final Report to the Secretary of State for Trade and Industry and the Chancellor

(2003), URN 03/567, Department of Trade and Industry, London.

Smith: Audit Committees: Combined Code Guidance, A report and proposed guidance by an FRC-appointed group chaired by Sir Robert Smith (2003), Financial Reporting Council, London.

DTI: Review of the Regulatory Regime of the Accountancy Profession: Report to the Secretary of State for Trade and Industry (2003), URN

03/589, Department of Trade and Industry, London.

\begin{tabular}{|c|c|}
\hline CGAA p. 17 & Yes \\
\hline CGAA p. 38 & Yes \\
\hline DTI, p. 5 & Yes \\
\hline CGAA p. 28 & Yes \\
\hline CGAA pp. 30-31 & Yes \\
\hline CGAA p. 19 & Yes \\
\hline CGAA p. 20 & Yes \\
\hline DTI p. 6 & No \\
\hline DTI p. 41 & No \\
\hline
\end{tabular}


The most significant difference between the Review Board's recommendations and the government's final recommendations is the establishment of a new audit monitoring unit to inspect listed and public interest audits. This unit will be under the control of the successor body to the Review Board, under the Financial Reporting Council, therefore the new Professional Oversight Board for Accountancy (POBA) will be responsible for ensuring its effectiveness. The POBA, as part of its continuing role, will monitor the effectiveness of the changes which have been brought in and recommend additional changes where appropriate.

This paper provides valuable insights into the nature of the sources of input to the UK's post-Enron reform programme for auditor independence. The Review Board's research programme, much of which was undertaken by independent academics, was put together in a very short time to ensure that the UK's government's final decision making process on auditor independence was evidence-based. The programme also provided evidence to support government instigated reviews of other aspects of the UK framework which were proceeding at the same time, particularly the Smith Report (FRC, 2003) and the Review of the Regulatory Framework of the Accountancy profession (DTI, 2003). This reform process represents an interesting example of evidence based policy making.

\section{ACKNOWLEDGEMENT}

The authors thank Sir John Bourn, Comptroller and Auditor General of the United Kingdom and Auditor General of Wales, for his advice and support in the development of this paper for publication. Sir John is Chairman of the UK Professional Oversight Board for Accountancy and was formerly Chairman of the Accountancy Foundation Review Board.

\section{NOTES}

1. The two Ministers were Melanie Johnson MP, Minister for Competition, Consumers and Markets and Ruth Kelly MP, Financial Secretary to the Treasury.

2. In addition to the CGAA Report, three other government instigated reports associated with the Enron collapse were issued in January 2003. These addressed: the role of the non-executive director (Higgs, 2003); audit committees (Financial Reporting Council, 2003) and the structure of the regulatory framework (DTI, 2003). In addition, the House of Commons Treasury Committee (2002) conducted its own inquiry.

3. The off balance sheet vehicles would not have been permitted under UK GAAP.

4. Before Andersen collapsed, the firm invited Paul Volker, the former head of the US Federal Reserve, to make recommendations about the future operation of the firm. Volker's proposals (Arthur Andersen, 2002) were intended to reduce risk and enhance independence. Risk would be reduced by improvement of internal quality control in the firm and stricter rules for client acceptance and retention decisions. Independence would be enhanced by the introduction of audit partner rotation and restrictions on audit staff joining clients (thus avoiding cosiness). There would also be restrictions on the provision of non-audit services and changes in the basis for audit partner performance incentives so that audit partners would be rewarded for good quality auditing rather than the selling of non-audit services.

5. The Accountancy Foundation was funded by the UK accounting bodies and consisted of: the Foundation Board, which made appointments; the Review Board which oversaw the education, disciplinary and audit regulatory activities of the accounting bodies; the Auditing Practices Board (APB), which set UK standards for auditors; the Ethics Standards Board (ESB), which oversaw the ethical standard setting of the professional bodies; and the Investigation and Discipline Board (IDB), which investigated major accounting scandals. The Review Board was responsible for scrutiny of the APB and the ESB. At the time of writing the activities of the Accountancy Foundation, with the exception of the ESB, are being transferred to the Financial Reporting Council. This follows the review by the DTI of the structure of regulation of the accountancy profession (DTI, 2003). The process is not yet complete. The accountancy professional bodies over which the Accountancy Foundation provided independent oversight constitute the Consultative Committee of Accountancy Bodies (CCAB). These are: The Institute of Chartered Accountants in England and Wales (ICAEW); 
The Institute of Chartered Accountants of Scotland (ICAS); The Institute of Chartered Accountants in Ireland (ICAI); The Association of Chartered Certified Accountants (ACCA); The Chartered Institute of Management Accountants (CIMA); and the Chartered Institute of Public Finance and Accountancy (CIPFA).

6. Before the CGAA made any recommendations for change to the independence framework, the Council of the Institute of Chartered Accountants in England and Wales (ICAEW) agreed to adopt as best practice the provisions of the 2002 Recommendation on Auditor Independence issued by the European Commission (EC, 2002) 'to the extent that they cover circumstances not specifically addressed' in the current UK framework. These provisions were approved by the ICAEW Council in October 2002. The principal differences between the framework applied by the ICAEW (i.e. the Chartered Accountants Joint Ethics Committee (CAJEC) Framework) and the EC recommendation are: greater restriction on non-audit services particularly IT and internal audit; audit engagement partner rotation every five years; and a ban on senior members of an audit team joining a client within two years of being engaged on the client's audit. At the time this review was carried out the ACCA had a separate ethics framework but this is of limited significance to the auditors of listed companies who are mainly regulated by the ICAEW.

7. The CGAA was set up in February 2002. An interim report was issued in July 2002 and the final report in January 2003.

8. The research was summarised by Professor Stella Fearnley of the University of Portsmouth Business School.

9. The DTI provided secretarial support to the CGAA.

10. See note 2 for details of the other reports.

11. Interestingly the financial journalists surveyed believed the level of non-audit services to be a much greater threat than the finance directors or audit partners.

12. The Financial Reporting Review Panel is the UK body which enforces company accounting compliance. The Panel has powers to apply to the court to require restatement of noncompliant accounts if directors do not take voluntary remedial action.
13. It is possible that this ratio may fall as a result of three of the Big Four (PricewaterhouseCoopers, Ernst and Young and KPMG) selling off their consulting practices.

14. Further details of the nature of these threats are shown in Table 2. Intimidation is the only threat which does not apply to non-audit services.

15. The frameworks compared are: UK, SEC, Australia, Ontario, International Federation of Accountants (IFAC) and the EC Recommendation.

16. The audit of central government functions is not subject to the mandatory rotation of auditors.

17. This framework was adopted by the three UK Institutes of Chartered Accountants who are responsible for the regulation of auditors of virtually all listed and public interest companies in the UK. The ACCA has a slightly different regime.

18. The Audit Regulations are issued by the UK professional accountancy bodies which are Recognised Supervisory Bodies for regulating auditors in the UK. The regulations referred to above are those issued by the three Institutes of Chartered Accountants. The ACCA has a slightly different regime.

19. The recently issued Companies Bill (December, 2003) proposes severe penalties for directors or company employees misleading auditors or failing to disclose material information to them.

20. The principal body responsible for reconsidering the role of the audit committee was Sir Robert Smith's group which was set up by the Financial Reporting Council. The Review Board research programme provided additional evidence in support of the Smith recommendations.

21. The Auditing Practices Board issued a consultation paper in November 2003 on ethical standards for auditors (APB, 2003).

\section{REFERENCES}

Accountancy Age (2002), 'Speech by Sir Howard Davis at the World Economic Forum', New York. (Reported 14 February.) London: VNU Publications, pp. 22-23.

Accountancy Foundation (2002), Independent Regulation of the Accountancy Profession, London: Accountancy Foundation.

Arthur Andersen (2002), 'Volker outlines framework for new Andersen with governing board', 
www.arthurandersen.com/websiten. . diaCentervolkerStmt32202, March 22, website visited 27 June, 2002.

APB (2003), Consultation Paper: Draft Ethical Standards for Auditors, London: APB Ltd.

Beattie, V., Fearnley, S. \& Brandt, R. (2001), Behind Closed Doors: What Company Audit is Really About, Basingstoke and New York: Palgrave.

Beattie, V., Fearnley, S. \& Brandt, R. (1999), 'Perceptions of auditor independence: UK evidence', Journal of International Accounting, Auditing and Taxation Vol. 8, No. 2, pp. 67-107.

CGAA (2002), Interim Report to the Secretary of State for Trade and Industry and the Chancellor of the Exchequer, URN 02/1092, Co-ordinating Group on Audit and Accounting issues, London: Department of Trade and Industry, July.

CGAA (2003), Final Report to the Secretary of State for Trade and Industry and the Chancellor of the Exchequer, URN 03/567, Co-ordinating Group on Audit and Accounting issues, London: Department of Trade and Industry, January.

CAJEC (1996), Integrity, Objectivity and Independence, Milton Keynes: Chartered Accountants Joint Ethics Committee.

Companies Act (1985), Department of Trade and Industry, London: Stationery Office.

Companies Act (1989), Department of Trade and Industry, London: Stationery Office.

Companies Bill (2003), Department of Trade and Industry. London: The Stationery Office.

De Angelo, (1981), 'Auditor size and audit quality', Journal of Accounting and Economics, Vol. 3, No. 2, pp. $183-199$.

DTI (2002), Review of the Regulatory Regime of the Accountancy Profession: A Consultation Document, London: Department of Trade and Industry, October.

DTI (2003), Review of the Regulatory Regime of the Accountancy Profession: Report to the Secretary of State for Trade and Industry, London: Department of Trade and Industry, January.

EC, (2002), Statutory Auditors' Independence in the EU: A Set of Fundamental Principles. Brussels: European Commission Recommendation 2001/6942.

FRC (2003), Audit Committees: Combined Code Guidance: A report and proposed guidance by an FRC appointed group chaired by Sir Robert Smith, London: Financial Reporting Council Limited, January.

Higgs, D. (2003), Review of the role and effectiveness of non-executive directors. London: Department of Trade and Industry, January.

Hinks, G. (2002), 'UK Accounting is top class', Accountancy Age, 4 July, p. 2.

House of Commons Treasury Committee (2002), The Financial Regulation of Public Listed Companies:
Sixth Report of Session 2001-02. Volume 1: Report and Proceedings of the Committee., London: The Stationery Office Limited.

ICAEW (1995), Audit Regulations and Guidance. London: Institute of Chartered Accountants in England and Wales.

IFAC (2001), Independence: Code of Ethics for Professional Accountants, New York: International Federation of Accountants.

ICAA (2002), Professional Statement F1: Professional Independence, Australia: Institute of Chartered Accountants in Australia.

ICAO (2002), ICAO Rules of Professional Conduct, [available at http://www.icao.ca/public/ handbook/rules95.html], Institute of Chartered Accountants of Ontario.

Kleinman, G. \& Palmon, D. (2001), Understanding Auditor-client Relations: a multi faceted analysis, Wiener, Princeton.

Modernising Company Law (2002), Government White Paper. (July). London: The Stationery Office Limited.

Sarbanes-Oxley Act (2002), Washington: One Hundred and Seventh Congress of the United States of America.

SEC (2000), Final Rule: Revision of the Commission's Auditor Independence Requirements, Washington: Securities and Exchange Commission.

SEC (2002), SEC Statement Regarding Andersen Case Conviction, Securities and Exchange Commission website, www.sec.gov/news/press/2002-89.htm visited 6.08.02.

\section{AUTHOR PROFILE}

Stella Fearnley is Professor of Accounting in the Department of Accounting and Law, University of Portsmouth Business School. She was an elected member of the Council of the Institute of Chartered Accountants in England and Wales from 1992-2004 and Deputy Chair of its Centre for Business Performance from 1996-2004. She is now a member of the UK's Professional Oversight Board for Accountancy.

Vivien Beattie is Professor of Accounting in the Department of Accounting and Finance, University of Glasgow. She held the part-time appointment of Director of Research of the Institute of Chartered Accountants of Scotland from 1997 until 2003 and is a member of the ASB's Academic Panel. Her main research interests are external audit and business reporting. 